\title{
PERBANDINGAN MAQASHID INDEX BANK UMUM SYARIAH DI INDONESIA DAN MALAYSIA
}

\author{
Hardman Satria \\ Bandar Lampung, Lampung \\ hardmansatria95@gmail.com \\ Ernie Hendrawaty, Muslimin \\ Jurusan Manajemen. Fakultas Ekonomi dan Bisnis, Universitas Lampung, Lampung \\ ernie.hendrawaty@feb.unila.ac.id ${ }^{1 a^{\rtimes}}$,muslimin.1975@feb.unila.ac.id ${ }^{b}$
}

\begin{abstract}
ABSTRAK
Riset ini bertujuan menguji perbedaan kinerja pada 11 bank syariah di Indonesia dengan 16 bank syariah di Malaysia berbasis pendekatan MSI (Maqashid Syariah Index). Riset ini ialah riset komparatif yang memakai uji beda independent sample t- test untuk mengidentifikasi perbandingan kinerja bank syariah di Indonesia dengan di Malaysia berbasis pendekatan maqashid indeks. Variabel independen pada riset ini merupakan 3 tujuan syariah dari maqashid indeks ialah pembelajaran orang, menghasilkan keadilan, serta kepentingan universal. Hasil riset disimpulkan bahwa kinerja bank syariah di Indonesia berbeda dengan kinerja bank syariah Malaysia berbasis pendekatan maqashid indeks.
\end{abstract}

Kata kunci: muqashid index, syariah, kinerja bank

\begin{abstract}
This research aims to test performance differences at 11 sharia banks in Indonesia with 16 sharia banks in Malaysia based on MSI (Maqashid Syariah Index) approach. This research is comparative research that uses a different independent sample $t$ - test to identify the comparison of sharia bank performance in Indonesia with malaysia-based index maqashid approach. Independent variables in this research are 3 sharia objectives of maqashid index is the learning of people, producing justice, as well as universal interests. The results concluded that the performance of sharia banks in Indonesia is different from the performance of Malaysian sharia banks based on the maqashid index approach.
\end{abstract}

Keywords: muqashid index, sharia, bank performance

\section{PENDAHULUAN}

Perbankan syariah adalah bagian dari ekonomi Islam yang akhir-akhir ini telah menjadi fokus perhatian dunia.Keberadaan perbankan syariah di era global semakin meluas karena warga telah menyadari keberadaan perbankan syariah.Perbankan syariah telah

${ }^{1} \times$ : Corresponding Author: ernie.hendrawaty@feb.unila.ac.id 
membuktikan kepada warga tentang daya tahan terhadap krisis keuangan global(Antonio et. al., 2012).Hingga kini perbankan syariah di dunia masih terus tumbuh terutama di daerah Asia Barat ataupun daerah Timur Tengah yang merupakan negara- negara dengan penduduk muslim. Asia Tenggara juga merupakan daerah dengan perkembangan perbankan syariah terbanyak di dunia.Terdapat dua negara di Asia Tenggara yang berpengaruh besar terhadap perkembagan perbankan syariah di dunia, yaitu Malaysia dan Indonesia sebagaimana dilaporkan oleh Top Islamic Financial Institusion. Indonesia dipandang sebagai negara yang mempunyai prospek besar dalam pertumbuhan keuangan syariah. Malaysia masih berada pada posisi dengan jumlah perbankan syariah terbanyak di Asia Tenggara.Kedua negeri tersebut merupakan negara dengan andil terbesar dalam pertumbuhan perbankan syariah di Asia Tenggara.

Perkembangan dan pertumbuhan perbankan syariah di Indonesia dan Malaysia terjadi karena ditunjang oleh kinerja perbankan syariah yang baik. Menurut Mohammed et. al. (2008) manajemen perbankan syariah belum dilakukan dengan baik, sehingga kinerja perbankan syariah masih diukur dengan memakai alat ukur konvensional yang berfokus pada pengukuran finansial.

Kuppusamy et. al. (2010), Muhaammed et. al. (2008), dan Hameed et. al. (2004) menyatakan bahwa maqashid indeksadalah pengukuran kinerja perbankan syariah yang didasarkan pada teroi Al-Maqashid Syariah.Indeks inimenjadi pendekatan strategis untuk menjelaskan kinerja perbankan syariah secara lebih baik, lebih luas dan komprehensif.

\section{KAJIAN LITERATUR}

\section{Teori Al-Maqashid Al-Syariah}

Maqashid Syariah menurut Zahrah (2010) adalah segala sesuatu yang ditetapkan oleh Allah dan Rasul-Nya dengan tujuan untuk menjaga eksistensi, mengembangkan baik kuantitasmaupun kualitas, sertaspiritualmaupun materialnya. Secara menyeluruh, tujuan Maqashid syariah diklasifikasikan dalam:

1. Kemaslahatan, adalah tujuan pokok yang hendak diraih dan terdapat dalam hokum islam. Tidak sekali-kali suatu perkara disyari'atkan oleh Islam melalui Al-qur'an dan As-sunnah melainkan di situ terkadang maslahat yang hakiki. Maslahat hakikiini menyangkut semua kepentingan umum, bukan kepentingan pihak tertentu (khusus).

2. Penyucian jiwa, agar setiap muslim bisa menjadi sumber kebaikan bukan sumber keburukan bagi masyarakat lingkungannya. Hal ini ditempuh dari berbagai ragam ibadah yang disyariatkan, yang kesemuanya dimaksudkan untuk membersihkan jiwa serta memperkokoh kesetiawanan sosial.

3. Keadilan, dalam masyarakat Islam adil baik urusan sesama kaum muslim maupun dalam berhubungan dengan pihak lain (non-muslim). Tujuan ditegakkannya keadilan dalam Islam amatlah luhur. Keadilan menyangkut berbagai aspek kehidupan.Islam memandang bahwa setiap orang mempunyai hak-hak yang sama, karena Islam memandang bahwa setiap orang itu tadi. Dalam usaha mewujudkan keadilan sosial, Islam sangat menjunjung tinggi hak-hak manusia.

\section{Kinerja Bank Syariah Berdasarkan Mawashid Syariah Indeks}

Maqashid syariah dibagi menjadi tiga kategori yaitu maslahah (keuntungan/kesejahteraan), tahzhib al-fard (pendidikan individu), dan iqamah al-adl (keadilan)(Antonio et. al., 2012). Konsep ini ditransformasikan menjadi sebuah pengukuran untuk mengevaluasi kinerja perbankan syariah.Hal itu dikarenakan sistem perbankan syariah sangat berbeda dengan perbankan konvensional.Perbedaan yang paling mendasar adalah terkait dengan nilai referensi (pandangan dunia syariah) untuk masing-masing asesmen keuangan. Perbedaan mendasar ini akan menyebabkan perbedaan formulasi atau 
penciptaan produk untuk kedua model perbankan termasuk masing-masing model evaluasi kinerja(Antonio et. al., 2012). Mohammed dan Taib (2015) dalam penelitiannya, telah memformulasikan evaluasi kinerja untuk perbankan syariah dengan mengacu pada konsep maqashid yariah. Variabel yang digunakan mengacu pada teori maqashid syariah yang dikemukakan oleh Zahrah (2010) yang meliputi tiga tujuan syariah.Tujuan pertama adalah tahzhib al-fard (pendidikan individu), kedua iqamah al-adl (keadilan), dan ketiga maslahah (kesejahteraan).Melalui konsep Sekaran (2000), ketiga maqashid tersebut telah diterjemahkan ke dalam dimensi dan diklasifikasikan menjadi beberapa elemen (Mohammed dan Taib 2015).

Ketiga dimensi maqashid syariah indeks yang diterapkan dan dikembangkan dalam penelitiannya oleh Mohammed dan Taib (2015) sehingga mendapatkan sebuah konsep sebagai berikut :

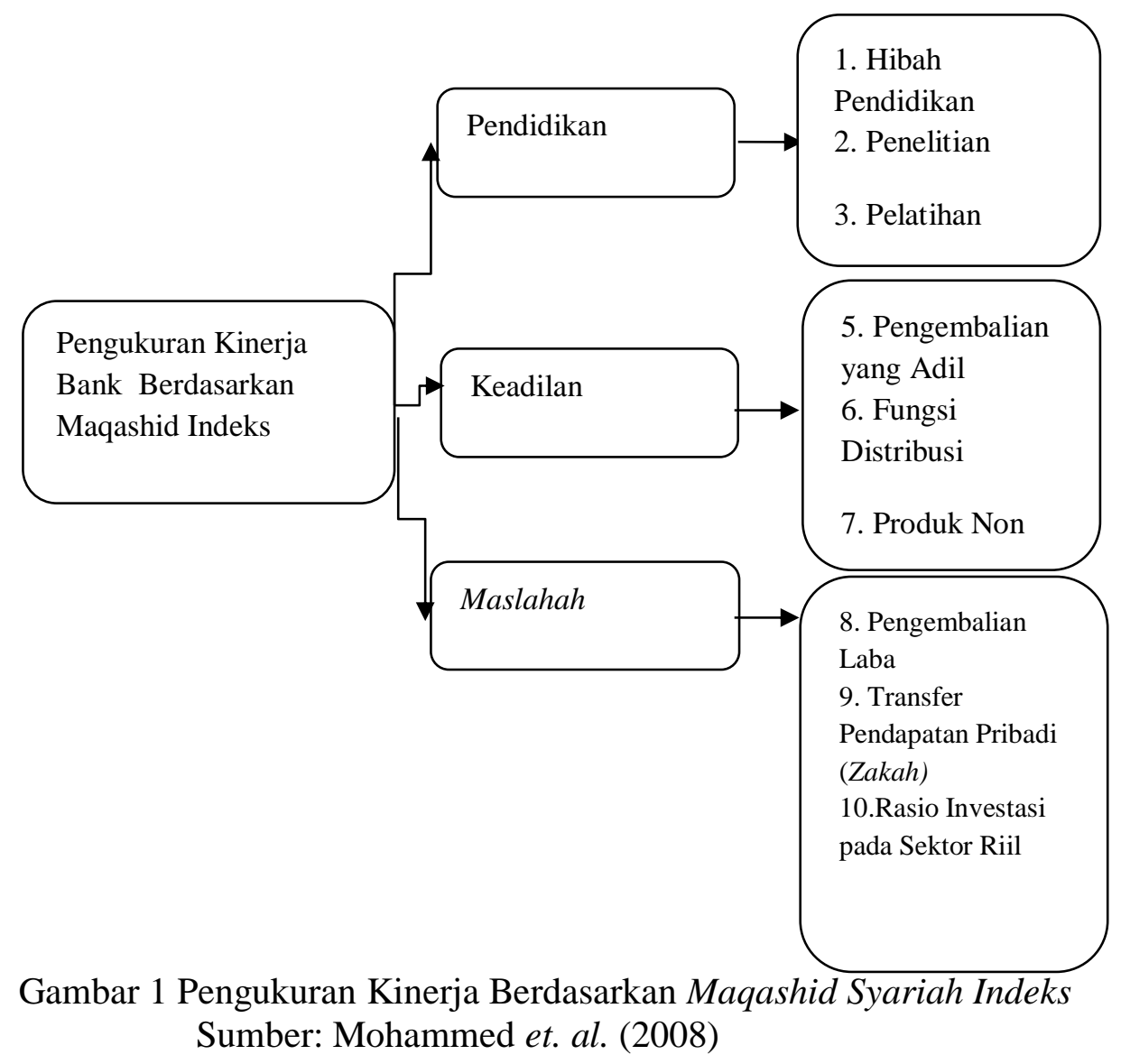

\section{Hipotesis}

$\mathrm{H}_{1}$ : Terdapat perbedaan Maqashid Syariah Indeks bank syariah di Indonesia dengan Malaysia

$\mathrm{H}_{2}$ :Terdapat perbedaan nilai Variabel Pendidikan Individu antara bank syariah Indonesia dengan Malaysia

$\mathrm{H}_{3}$ : Terdapat perbedaan nilai Variabel Menciptakan Keadilan antara bank syariah Indonesia dengan Malaysia

$\mathrm{H}_{4}$ : Terdapat perbedaan nilai Variabel Kepentingan Umum antara bank syariah di Indonesia dengan Malaysia 


\section{METODE PENELITIAN}

Penelitian ini merupakan jenis penelitian deskriptif, karena analisis pada penelitian ini mencoba mendeskripsikan variabel dari Maqashid Indeks satu demi satu secara sistematik dan faktual sehingga menujukkan nilai kinerja pada bank umum yang dijadikan populasi.

Penelitian ini juga merupakan penelitian komparatif. Menurut Arikunto (2019), penelitian komparatif bertujuan untuk menemukan persamaan-persamaan dan perbedaaanperbedaan tentang benda-benda, tentang orang, tentang prosedur kerja, tetnang ide-ide, kritik terhadap orang lain, kelompok, terhadap suatu idea atau prosedur kerja.

\section{Sampel Penelitian}

Sampel dalam penelitian ini diambil menggunakan metode purposive sampling dengan memilih sampel berdasarkan kriteria Bank umum syariah yang terdaftar dalam Bank Indonesia dan Bank Negara Malaysia sejak tahun 2013-2017 serta memiliki Annual Report lengkap Berdasarkan kriteria diperoleh 11 Bank Umum Syariah di Indonesia dan 16 Bank Umum Syariah di Malaysia.

\section{Pengukuran Variabel}

\section{a. Penentuan Rasio Kinerja}

Variabel dalam penelitian ini adalah kinerja bank umum syariah secara keseluruhan berdasarkan pendekatan Maqashid Syariah Indeks (MSI).Tiga tujuan bank syariah adalah Pendidikan Individu, Menciptakan Keadilan, dan Kepentingan Umum.

Menurut Mohammed et. al. (2008) Pendidikan Individu dapat diturunkan menjadi empat rasio, yaitu: Hibah Pendidikan/Total Biaya, Biaya Penelitian/Total Biaya, Biaya Pelatihan/Total Biaya dan Biaya Publikasi/Total Biaya

Menurut Mohammed et. al. (2008) Menciptakan Keadilan dapat diturunkan menjadi tiga rasio, yaitu: Laba/Total Pendapatan, Piutang tak Tertagih/Total Investasi dan Pendapatan Non Bunga/Total Pendapatan

Menurut Mohammed et. al. (2008) Kepentingan Umum dapat diturunkan menjadi 3 rasio, yaitu: Laba Bersih/Total Aset, Zakat/Total Pendapatan dan Penyaluran Investasi pada Sektor riil/Total Investasi

\section{b. Pembobotan Kinerja}

Tahap pertama dalam pengukuran kinerja bank syariah dengan menggunakan Maqashid Indeks Antonio, et. al. (2012) adalah:

1. Menghitung rasio kinerja di masing-masing bank umum syariah.

2. Menentukan pembobotan untuk masing-msaing nilai tujuan syariah sesuai dengan BTS (Bobot Tujuan Syariah).

3. Melakukan pembobotan untuk masing-masing nilai Maqashid Syariah Indeks (MSI) sesuai dengan BTS (Bobot Tujuan Syariah).

4. Menjumlahkan rasio-rasio untuk mengetahui nilai tujuan-tujuan syariah kedua negara.

Rumus menjumlahkan rasio yang digunakan untuk mengetahui nilai tujuan syariah kedua negara menurut (Hartono et.al., 2017) adalah sebagai berikut:

$$
\begin{aligned}
& \mathrm{P}_{\mathrm{I}}\left(\mathrm{O}_{1}\right)=\left(\mathrm{W}_{1} \times \mathrm{E}_{1.1} \times \mathrm{R}_{1.1}\right)+\left(\mathrm{W}_{1} \times \mathrm{E}_{.1 .2} \times \mathrm{R}_{1.2}\right)+\left(\mathrm{W}_{1} \times \mathrm{E}_{1.3} \times \mathrm{R}_{1.3}\right)+\left(\mathrm{W}_{1} \times \mathrm{E}_{1.4} \times \mathrm{R}_{1.4}\right) \\
& \mathrm{P}_{\mathrm{I}}\left(\mathrm{O}_{2}\right)=\left(\mathrm{W}_{2} \times \mathrm{E}_{2.1} \times \mathrm{R}_{2.1}\right)+\left(\mathrm{W}_{2} \times \mathrm{E}_{.2 .2} \times \mathrm{R}_{2.2}\right)+\left(\mathrm{W}_{2} \times \mathrm{E}_{2.3} \times \mathrm{R}_{2.3}\right) \\
& \mathrm{P}_{\mathrm{I}}\left(\mathrm{O}_{3}\right)=\left(\mathrm{W}_{3} \times \mathrm{E}_{3.1} \times \mathrm{R}_{3.1}\right)+\left(\mathrm{W}_{3} \times \mathrm{E}_{.3 .2} \times \mathrm{R}_{3.2}\right)+\left(\mathrm{W}_{3} \times \mathrm{E}_{3.3} \times \mathrm{R}_{3.3}\right)
\end{aligned}
$$


Keterangan:

$\mathrm{P} \quad=$ Performance Indeks

$\mathrm{W} \quad=$ Bobot nilai Tujuan Syariah

$\mathrm{E} \quad=$ Bobot Elemen

$\mathrm{R} \quad=$ Nilai Rasio

Tabel 1 menujukkan bobot yang diberikan dari masing-masing variabel dan elemenelemen yang menjadi tolak ukur dari Maqashid Indeks berdasarkan penelitian terdahulu yang dilakukan oleh Mohammed et.al. (2008).

Tabel 1. Rata-rata Bobot Nilai dari Tiga Tujuan Syariah dan 10 Elemen Maqashid Indeks.

\begin{tabular}{|c|c|c|c|}
\hline Tujuan & $\begin{array}{c}\text { Rata - } \\
\text { Rata } \\
\text { Bobot } \\
\text { (Dari } \\
100 \%)\end{array}$ & Elemen - Elemen & $\begin{array}{l}\text { Rata - Rata Bobot } \\
(\text { Dari 100\%) }\end{array}$ \\
\hline \multirow{5}{*}{$\begin{array}{l}\text { 01. Pendidikan } \\
\text { (Tadhib al-Fard) }\end{array}$} & \multirow{5}{*}{30} & E1. Hibah Pendidikan & 24 \\
\hline & & E2. Penelitian & 27 \\
\hline & & E3. Pelatihan & 26 \\
\hline & & E4. Publikasi & 23 \\
\hline & & Total & 100 \\
\hline \multirow{4}{*}{$\begin{array}{l}\text { 02.Menciptakan } \\
\text { Keadilan (Ad-`Adl) }\end{array}$} & \multirow[t]{4}{*}{41} & E5. Pengembalian Yang Adil & 30 \\
\hline & & E6. Fungsi Distribusi & 32 \\
\hline & & E7. Produk Non-Bunga & 38 \\
\hline & & Total & 100 \\
\hline \multirow{4}{*}{$\begin{array}{l}\text { 03. Kepentingan } \\
\text { Umum }\end{array}$} & \multirow[t]{4}{*}{29} & E8.Rasio Keuntungan & 33 \\
\hline & & E9.Pendapatan Personal & 30 \\
\hline & & E10.Rasio Investasi pada sektor Riil & 27 \\
\hline & & Total & 100 \\
\hline Total & 100 & Total & 100 \\
\hline
\end{tabular}

\section{HASIL PENELITIAN DAN PEMBAHASAN}

Tabel 2 menyajikan Statistik Deskriptif Performance Indeks Bank Umum Syariah di Indonesia dan Malaysia.

Tabel 2 Statistik Deskriptif Performance Indeks Bank Umum Syariah di Indonesia dan Malaysia

\begin{tabular}{|r|l|r|r|r|r|}
\hline \multicolumn{6}{|c|}{ BANK UMUM SYARIAH NEGARA INDONESIA } \\
\hline NO & BANK & PI1 & PI2 & PI3 & MI \\
\hline 1 & BCA Syariah & $0,15 \%$ & $16,32 \%$ & $2,59 \%$ & $19,06 \%$ \\
\hline 2 & BJB Syariah & $0,08 \%$ & $11,31 \%$ & $0,33 \%$ & $11,71 \%$ \\
\hline 3 & BNI Syariah & $6,04 \%$ & $15,64 \%$ & $0,74 \%$ & $22,41 \%$ \\
\hline 4 & BRI Syariah & $0,31 \%$ & $16,08 \%$ & $1,06 \%$ & $17,45 \%$ \\
\hline 5 & BUKOPIN & $0,39 \%$ & $14,96 \%$ & $0,42 \%$ & $15,77 \%$ \\
\hline 6 & BSM & $0,23 \%$ & $11,83 \%$ & $1,03 \%$ & $13,08 \%$ \\
\hline 7 & MAYBANK IND & $0,42 \%$ & $14,26 \%$ & $4,31 \%$ & $18,98 \%$ \\
\hline 8 & MEGA Syariah & $0,09 \%$ & $13,92 \%$ & $7,75 \%$ & $21,76 \%$ \\
\hline 9 & MUAMALAT IND & $0,44 \%$ & $15,23 \%$ & $0,17 \%$ & $15,84 \%$ \\
\hline 10 & PANIN Syariah & $0,29 \%$ & $13,38 \%$ & $1,70 \%$ & $15,36 \%$ \\
\hline 11 & VICTORIA Syariah & $0,09 \%$ & $15,21 \%$ & $0,29 \%$ & $15,59 \%$ \\
\hline Minimum & $0,08 \%$ & $11,31 \%$ & $0,17 \%$ & $11,71 \%$ \\
\hline Maximum & $6,04 \%$ & $16,32 \%$ & $7,75 \%$ & $22,41 \%$ \\
\hline Average & $0,77 \%$ & $14,38 \%$ & $1,85 \%$ & $17,00 \%$ \\
\hline Std.Dev & $1,75 \%$ & $1,65 \%$ & $2,32 \%$ & $3,33 \%$ \\
\hline
\end{tabular}


Tabel 2 Statistik Deskriptif Performance Indeks Bank Umum Syariah di Indonesia dan Malaysia (Lanjutan)

\begin{tabular}{|r|r|r|r|r|r|}
\hline \multicolumn{7}{|c|}{ BANK UMUM SYARIAH NEGARA MALAYSI } \\
\hline 1 & Affin Islamic Bank & $1,41 \%$ & $2,60 \%$ & $0,15 \%$ & $4,16 \%$ \\
\hline 2 & Al-Rajhi Bank & $3,22 \%$ & $6,39 \%$ & $2,51 \%$ & $12,12 \%$ \\
\hline 3 & Alliance Islamic Bank & $0,37 \%$ & $6,37 \%$ & $0,84 \%$ & $7,58 \%$ \\
\hline 4 & Am Bank Islamic & $1,37 \%$ & $6,58 \%$ & $1,28 \%$ & $9,22 \%$ \\
\hline 5 & Asian Finance Bank Berhad & $0,67 \%$ & $9,97 \%$ & $0,19 \%$ & $10,83 \%$ \\
\hline 6 & Bank Islam Malaysia & $1,36 \%$ & $14,50 \%$ & $0,75 \%$ & $8,89 \%$ \\
\hline 7 & Bank Muamalat Malaysia & $1,08 \%$ & $12,75 \%$ & $3,81 \%$ & $9,49 \%$ \\
\hline 8 & CIMB Islamic Bank & $0,21 \%$ & $10,64 \%$ & $0,11 \%$ & $10,96 \%$ \\
\hline 9 & Hong Leong Islamic Bank & $0,30 \%$ & $3,54 \%$ & $0,82 \%$ & $4,66 \%$ \\
\hline 10 & HSBC Amanah Malaysia & $0,63 \%$ & $3,10 \%$ & $0,45 \%$ & $4,18 \%$ \\
\hline 11 & Kuwait Finance House Berhad & $1,28 \%$ & $1,36 \%$ & $0,39 \%$ & $3,02 \%$ \\
\hline 12 & Maybank Islamic Berhad & $0,30 \%$ & $4,36 \%$ & $5,38 \%$ & $10,05 \%$ \\
\hline 13 & OCBC Al- Amin Bank & $0,38 \%$ & $4,01 \%$ & $0,26 \%$ & $4,65 \%$ \\
\hline 14 & Public Islamic Bank & $0,16 \%$ & $3,75 \%$ & $0,13 \%$ & $4,04 \%$ \\
\hline 15 & RHB Islamic Bank Behad & $0,27 \%$ & $7,44 \%$ & $0,34 \%$ & $8,05 \%$ \\
\hline 16 & Standard Chartered Saadiq & $0,79 \%$ & $3,07 \%$ & $0,03 \%$ & $3,89 \%$ \\
\hline Minimum & $0,16 \%$ & $1,36 \%$ & $0,03 \%$ & $3,02 \%$ \\
\hline Maximum & $3,22 \%$ & $14,50 \%$ & $5,38 \%$ & $12,12 \%$ \\
\hline Average & $0,86 \%$ & $6,28 \%$ & $1,09 \%$ & $7,24 \%$ \\
\hline Std.Dev & $0,78 \%$ & $3,87 \%$ & $1,53 \%$ & $3,08 \%$ \\
\hline
\end{tabular}

Tabel 2 menunjukkan bahwa nilai $\mathrm{P}_{\mathrm{I} 1}, \mathrm{P}_{\mathrm{I} 2}, \mathrm{P}_{\mathrm{I} 3}$, dan maqashid indeks bank syariah sntara bank Indonesia dan Malaysia menunjukkan bahwa tiga dari empat nilai dari bank syariah Indonesia lebih unggul dari bank syariah Malaysia. Nilai minimum $\mathrm{P}_{\mathrm{I} 1}$ bank syariah Indonesia yang lebih rendah dibandingkan bank syariah Malaysia. Hasil ini menunjukkan bahwa bank syariah Malaysia memiliki kinerja paling rendah dalam mewujudkan tujuan syariah atau maqashidh indeks.

Hasil analisis juga menunjukkan bahwa nilai maksimum $\mathrm{P}_{\mathrm{I} 1}, \mathrm{P}_{\mathrm{I} 2}, \mathrm{P}_{\mathrm{I} 3}$, dan maqashid indeks bank syariah Indonesia secara keseluruhan lebih besar dibandingkan dengan nilai maksimum yang didapatkan bank syariah Malaysia.

Nilai rata-rata dari $\mathrm{P}_{11}, \mathrm{P}_{\mathrm{I} 2}, \mathrm{P}_{\mathrm{I}}$, dan maqashid indeks bank syariah Indonesia secara keseluruhan juga lebih besar dibandingkan dengan nilai rata-rata $\mathrm{P}_{\mathrm{I} 1}, \mathrm{P}_{\mathrm{I} 2}, \mathrm{P}_{\mathrm{I}}$, dan maqashid indeks bank syariah Malaysia. Hasil perhitungan nilai rata-rata menujukkan bahwa kinerja bank syariah yang ada di Indonesia lebih unggul dalam mewujudkan tujuan syariah dibandingkan dengan kinerja bank syariah di Malaysia.

\section{Analisis Performance Indeks}

\section{Performance Indeks Pertama (Pendidikan Individu)}

Berdasarkan hasil yang didapatkan dari perhitungan $\mathrm{P}_{\mathrm{I} 1}$, dapat diketahui bahwa hampir seluruh bank syariah di Indonesia masih belum cukup baik kontribusinya dalam bidang pendidikan yang merupakan salah satu tujuan dari maqashid indeks. Hal ini terlihat dari nilai $\mathrm{P}_{\mathrm{II}} 10$ bank syariah di Indonesia masih dibawah nilai rata-rata. Bank syariah di Malaysia terdapat 6 bank syariah yang mendapatkan nilai $\mathrm{P}_{\mathrm{I} 1}$ diatas rata-rata, hal ini menunjukkan kontribusi bank syariah di negara Malaysia dibidang pendidikan lebih baik di banding bank syariah di Indonesia. Hasil ini juga berbanding lurus dengan angka market share bank syariah di kedua negara. 


\section{Performance Indeks Kedua (Menciptakan Keadilan)}

Hasil dari perhitungan $\mathrm{P}_{\mathrm{I} 1}$ ini menunjukkan bahwa, Bank syariah yang mendapatkan nilai tertinggi pada $\mathrm{P}_{\mathrm{I} 2}$ (menciptakan keadilan) adalah $\mathrm{BCA}$ Syariah. Nilai $\mathrm{P}_{\mathrm{I} 2}$ yang didapatkan BCA Syariah adalah 16,32\%. Peringkat kedua ditempati oleh BRI Syariah, kemudian di peringkat ketiga adalah BNI Syariah. Masing-masing memperoleh nilai $\mathrm{P}_{\mathrm{I} 2}$ sebesar $16,08 \%$ dan $15,64 \%$.

Hasil perhitungan juga menujukkan bahwa hasil perhitungan $\mathrm{P}_{\mathrm{I} 2}$ yang terdiri dari rasio pengembalian yang adil, rasio distribusi fungsional, dan rasio produk bebas bunga, rata-rata bank syariah di Indonesia lebih unggul dibandingkan dengan rata-rata bank syariah di Malaysia. $\mathrm{P}_{\mathrm{I} 2}$ bank syariah di Indonesia adalah $14,38 \%$, sedangkan rata-rata $\mathrm{P}_{\mathrm{I} 2}$ bank syariah di Malaysia adalah 6,28\%. Nilai rata-rata $\mathrm{P}_{\mathrm{I} 2}$ secara keseluruhan dari kedua neagara adalah sebesar 9,58\%. Angka ini menunjukkan bahwa dari target tujuan syariah menciptakan keadilan yaitu $100 \%$, secara rata-rata kinerja bank syariah Indonesia dan Malaysia baru mencapai angka 9,58\%.

Hasil perhitungan juga menunjukkan bahwa 11 bank syariah di Indonesia memiliki nilai $P_{I 2}$ diatas nilai rata-rata, sedangkan di negara Malaysia hanya 4 bank saja yang mendapatkan nilai $\mathrm{P}_{\mathrm{I} 2}$ diatas rata-rata yaitu Asian Finance Bank Berhad, Bank Islam Malaysia, Bank Muamalat Malaysia, dan Bank Kuwait Finance House Berhad. Hasil ini menunjukkan bahwa kinerja bank syariah di Indonesia dalam mewujudkan tujuan syariah menciptakan keadilan lebih baik dibandingkan dengan bank syariah Malaysia.

\section{Performance Indeks Ketiga (Kepentingan Umum)}

Bank syariah Indonesia walaupun secara rata-rata mendapatankan nilai yang lebih rendah pada hasil pengukuran rasio profitabilitas dan rasio pendapatan personal. Bank syariah Indonesia unggul pada rasio investasi sektor riil dengan mendapatkan nilai rata-rata sebesar 24,1\% sedangkan bank syariah Malaysia mendapatkan nilai rata-rata sebesar 11,4\%. Hasil ini menunjukkan bahwa dari total seluruh investasi yang disalurkan, bank syariah di Indonesia rata-rata menyalurkan $24,1 \%$ dana investasi ke bidang sektor riil, sedangkan bank syariah Malaysia rata-rata menyalurkan $11,4 \%$ dana investasinya ke bidang sektor riil. Hasil ini menunjukkan bahwa bank syariah Indonesia lebih unggul kinerjanya dalam mendukung pergerakan sektor riil yang merupakan sektor yang bersentuhan langsung dengan kegiatan ekonomi masyarakat, yang keberadaannya dapat dijadikan tolok ukur untuk mengetahui pertumbuhan ekonomi. Semakin besar dana investasi yang disalurkan ke sektor riil tentu akan berdampak baik pada pergerakan sektor riil di negara tersebut yang kemudian akan mewujudkan kesejahateraan masyarakatnya.

\section{Maqashid Indeks}

Berdasarkan perhitungan, jika diambil nilai rata-rata maqashid indeks dari keseluruhan bank syariah Indonesia dan bank syariah Malaysia. Nilai rata-rata yang didapatkan bank syariah Indonesia adalah sebesar 17,00\%, sedangkan bank syariah Malaysia mendapatkan nilai 7,24\%. Angka ini menunjukkan bahwa kinerja bank syariah bedarsarkan tujuan syariah atau maqashid indeks baru mencapai angka 17,00\% dari target pencapaian $100 \%$. Pencapaian tersebut lebih tinggi dibandingkan kinerja bank syariah di Malaysia yang mendapatkan nilai rata-rata maqashid indeks sebesar 7,24\%, yang berarti dari target pencapaian $100 \%$ secara rata-rata kinerja bank syariah Malaysia dalam mewujudkan tujuan syariah baru mencapai angka $7,24 \%$.

Berdasarkan hasil ini dapat dikatakan bahwa kinerja bank syariah di negara Indonesia dilihat dari nilai maqshid indeks secara individu bank syariah, maupun nilai ratarata maqashid indeks yang beroperasi diIndonesia dalam mewujudkan tujuan syariah dapat 
dikatakan lebih baik dibandingkan dengan kinerja bank syariah di Malaysia dalam mewujudkan tujuan syariah.

\section{Hasil Uji Beda Independent Sample T-test}

\section{Hasil Uji Beda Independent Sample T-test Maqashid Syariah Indeks.}

Hasil analisis uji beda nilai variabel maqashid indeks bank syariah Indonesia dan Malaysia diatas menunjukkan angka sig.(2-tailed) sebesar 0,000. Artinya, terdapat perbedaan antara nilai rata-rata varibel maqashid syariah indeks bank syariah Indonesia dengan nilai rata-rata variabel maqashid indeks bank syariah Malaysia.

\section{Hasil Uji Beda Independent Sample T-test Performance Indeks Pendidikan Individu.}

Hasil analisis uji beda independent sample t-test nilai variabel pendidikan individu bank syariah Indonesia dan Malaysia mendapatkan angka sig.(2-tailed) senilai 0,879. Artinya, tidak terdapat perbedaan antara nilai rata-rata varibel pendidikan individu bank syariah Indonesia dengan nilai rata-rata variabel pendidikan individu bank syariah Malaysia.

\section{Hasil Uji Beda Independent Sample T-test Performance Indeks Menciptakan Keadilan.}

Berdasarkan pada tabel hasil analisis uji bedaindependent sample t-test nilai variabel menciptakan keadilan diantara bank syariah Indonesia dan Malaysia diatas. Angka sig.(2tailed) yang didapatkan adalah 0,000 yang artinya, terdapat perbedaan antara nilai rata-rata varibel menciptakan keadilan bank syariah Indonesia dengan bank syariah Malaysia, maka Hipotesis yang menyatakan bahwa terdapat perbedaan nilai variabel menciptakan keadilan diantara bank umum syariah Indonesia dengan Malaysia tahun 2013-2017 diterima.

\section{Analisis Uji Beda Independent Sample T-test Performance Indeks Kepentingan Individu.}

Berdasarkan hasil analisis uji beda independent sample t-testangka sig.(2-tailed) yang didapatkan adalah 0,351yang artinya, tidak terdapat perbedaan antara nilai rata-rata varibel kepentingan umum bank syariah Indonesia dengan nilai rata-rata variabel kepentingan umum bank syariah Malaysia. Hipotesis yang menyatakan bahwa terdapat perbedaan nilai variabel kepentingan umum diantara bank umum syariah Indonesia dengan Malaysia tahun 2013-2017 ditolak. Hasil ini menunjukkan bahwa kinerja kepentingan umum bank syariah Indonesia dengan bank syariah Malaysia secara rata-rata sama.

\section{PENUTUP}

Hasil penelitian menunjukkan bahwa perbankan syariah di Indonesia memiliki nilai kinerja yang lebih unggul berdasarkan maqashid indeks.Perbankan syariah Indonesia unggul dalam nilai kinerja performance indeks menciptakan keadilan, performance indeks kepentingan umum, dan juga unggul dalam nilai kinerja maqashid indeks keseluruhan.Perbankan syariah Malaysia hanya unggul dalam performance indeks pendidikan individu.Hasil uji beda menunjukkan bahwa ada perbedaan signifikan kinerja perbankan syariah Indonesia dan Malaysia dalam performance indeks menciptakan keadilan dan kinerja maqashid indeks. Sedangkan, hasil uji beda menunjukkan tidak ada perbedaan signifikan performance indeks pendidikan individu, dan performance indeks kepentingan umum.

Berdasarkan hasil disimpulkan bahwa kinerja bank syariah di negara Indonesia berbasis nilaimaqshid indeks di Indonesia dapat dikatakan lebih baik dibandingkan dengan kinerja bank syariah di Malaysia dalam mewujudkan tujuan syariah.Hasil penelitian yang 
didapatkan pada rasio produk non bunga, menunjukkan bahwa bank syariah di Malaysia secara rata-rata pendapatannya lebih besar bersumber dari selain pendapatan produk nonbunga.

Kelemahan penelitian adalah kesulitan dalam mencari data angka yang menjadi komponen perhitungan rasio kinerja, seperti data dari besarnya biaya yang dikeluarkan perusahaan untuk pendidikan, penelitian, pelatihan dan publikasi.Terdapat beberapa bank syariah yang tidak mencantumkan besarnya biaya tersebut.

\section{DAFTAR RUJUKAN}

Antonio, M. S., Sanrego, Y. D., \& Taufiq, M. (2012).An analysis of Islamic banking performance: Maqashid index implementation in Indonesia and Jordania. Journal of Islamic Finance, 1(1).

Arikunto, S. (2019).Prosedur penelitian suatu pendekatan praktik.Jakarta: PT. Rineka Cipta

Hameed, S., Sigit P., Bakhtiar N. (2004).Alternative Disclosure and Performance Measures for Islamic Banks.Malaysia:IIUM.

Hartono, S., \& Sobari, A. (2017). Sharia maqashid index as a measuring performance of Islamic banking: a more holistic approach. Corp. Ownersh. Control, 14(2), 193-201.

Kuppusamy, M., Saleh, A. S., \& Samudhram, A. (2010).Measurement of Islamic banks performance using a shariah conformity and profitablity model. Review of Islamic Economics, 13(2), 35-48.

Mohammed, M. O., Dzuljastri A. R., Taib, F. M. (2008). The Performance Measures of Islamic Banking Based on the Maqashid Framework. IIUM Intrenational Accounting Conference (INTAC IV)held at Putra Jaya Marriott. pp. 1-17.

Mohammed, M. O., \& Taib, F. M. (2015). Developing Islamic banking performance measures based on Maqasid al-Shari'ah framework: Cases of 24 selected banks. Journal of Islamic Monetary Economics and Finance, 1(1), 55-77.

Sekaran, U. (2000). Research methods for business: a skill building approach.New York: John Wiley \& Sons.

Zahrah, M. A. (2010). Ushul Fiqih (terj) cet. ke-13. Jakarta: Pustaka Firdaus. 